\title{
Increased frequency of $\beta$ cells with abnormal NKX6.1 expression in type 2 diabetes but not in subjects with higher risk for type 2 diabetes
}

Tengli Liư ${ }^{1,2}$, Peng Sun², Jiaqi Zou², Le Wang², Guanqiao Wang², Na Liu², Yaojuan Liu², Xuejie Ding², Boya Zhang ${ }^{2}$, Rui Liang ${ }^{2}$, Shusen Wang ${ }^{1,2,3^{*}}$ (iD and Zhongyang Shen ${ }^{2}$

\begin{abstract}
Background: NKX6.1 is a transcription factor for insulin, as well as a marker for $\beta$ cell maturity. Abnormal NKX6.1 expression in $\beta$ cells, such as translocation from the nucleus to cytoplasm or lost expression, has been shown as a marker for $\beta$ cell dedifferentiation.

Methods: We obtained pancreatic sections from organ donors and immunofluorescence staining with NKX6.1 and insulin was performed to characterize NKX6.1 expression in subjects with or without type 2 diabetes mellitus (T2DM).

Results: Our results showed that cells with insulin expression but no nucleic NKX6.1 expression (NKX6.1 ${ }^{\text {Nuc- }}{ }^{\text {Ins }}{ }^{+}$), and cells with cytoplasmic NKX6.1 expression but no insulin expression (NKX6.1 ${ }^{\text {cyt }}$ Ins ${ }^{-}$) were significantly increased in T2DM subjects and positively correlated with glycated hemoglobin ( $\mathrm{HbA} 1 \mathrm{c})$, indicating the elevated $\beta$ cell dedifferentiation with NKX6.1 inactivation in T2DM. To investigate whether $\beta$ cell dedifferentiation has initiated in subjects with higher risks for T2DM, we next analyzed the association between $\beta$-cell dedifferentiation level in ND subjects with different ages, body mass index, and $\mathrm{HbA1c}$. The results showed the absolute number and percentage of dedifferentiated $\beta$ cells with NKX6.1 inactivation did not significantly change in subjects with advanced aging, obesity, or modest hyperglycemia, indicating that the $\beta$ cell dedifferentiation might mainly occur after T2DM was diagnosed.

Conclusion: Our results suggested that NKX6.1 expression in $\beta$ cells was changed in type 2 diabetic subjects, evidenced by significantly increased NKX6.1 ${ }^{\mathrm{Nuc}^{-}} \mathrm{Ins}^{+}$and NKX6.1 $1^{\mathrm{cyt}} \mathrm{Ins}{ }^{-}$cells. This abnormality did not occur more frequently in subjects with a higher risk for T2DM, suggesting that $\beta$ cell dedifferentiation might be secondary to the pathological changes in T2DM.
\end{abstract}

Keywords: NKX6.1, Age, Obesity, HbA1c, $\beta$-Cell dedifferentiation

\footnotetext{
* Correspondence: shusen@vip.163.com

'Organ Transplant Center, Tianjin First Central Hospital, Nankai University, Building A, Fukang Road 24\#, Nankai area, Tianjin City 300192, China

${ }^{2} \mathrm{NHC}$ Key Laboratory for Critical Care Medicine, Tianjin First Central Hospital, Tianjin 300384, China

Full list of author information is available at the end of the article
}

(c) The Author(s). 2021 Open Access This article is licensed under a Creative Commons Attribution 4.0 International License, which permits use, sharing, adaptation, distribution and reproduction in any medium or format, as long as you give appropriate credit to the original author(s) and the source, provide a link to the Creative Commons licence, and indicate if changes were made. The images or other third party material in this article are included in the article's Creative Commons licence, unless indicated otherwise in a credit line to the material. If material is not included in the article's Creative Commons licence and your intended use is not permitted by statutory regulation or exceeds the permitted use, you will need to obtain permission directly from the copyright holder. To view a copy of this licence, visit http://creativecommons.org/licenses/by/4.0/ The Creative Commons Public Domain Dedication waiver (http://creativecommons.org/publicdomain/zero/1.0/) applies to the data made available in this article, unless otherwise stated in a credit line to the data. 


\section{Background}

463 million adults are currently affected by diabetes worldwide in 2019, around 90\% of which are type 2 diabetes mellitus (T2DM) [1]. There are 116 million diabetic patients in China, being the largest in the world [1, $2]$. $\beta$-cell deficit is one of the root causes in the development of type 2 diabetes [3, 4], and our previous study showed a significant decrease in $\beta$-cell mass in Chinese patients with type 2 diabetes [5]. One of the main causes of $\beta$-cell deficit in type 2 diabetes is the loss of key transcription factors in $\beta$ cells, which makes $\beta$ cells back to a "dedifferentiated" state, including the homeobox protein NKX6.1 [6-8]. NKX6.1 is one of the key transcription factors that are engaged in early and late pancreatic $\beta$ cell specification [9]. The gene regulatory network controlled by transcription factor NKX6.1 is also necessary to maintain the function and identity of mature $\beta$ cells $[10,11]$, and the overexpression of $\mathrm{Nkx6.1}$ in adult mouse $\beta$ cells of mice resulted in elevated glucose stimulated insulin secretion (GSIS) [10], yet the inactivation of Nkx6.1 could lead to a decrease in insulin secretion, causing diabetes [11]. Meanwhile, Nkx6.1 inactivation in adult mouse $\beta$ cells could [11] induce the expression of progenitor cell markers $[6,7,11-13]$, which exhibited a dedifferentiation stage. These results are consistent with the findings that NKX6.1 expression is decreased in $\beta$ cells from obese-diabetic mice and human T2DM islets compared with that in non-diabetic ones [7, 14]. Therefore, NKX6.1 inactivation has been used as a protein marker for $\beta$ cell dedifferentiation.

It has been reported that using NKX6.1 staining can discriminate a subset of dedifferentiated $\beta$ cells, and the NKX6.1 defined $\beta$ cell dedifferentiation level is elevated in T2DM patients or T2DM animal models. However, whether $\beta$ cell dedifferentiation has higher level in subjects with higher risks for diabetes compared with those with lower risks is unknown. The present study hypothesized that $\beta$ cell dedifferentiation level is higher in the former than in the latter. To test our hypothesis, we evaluated the $\beta$ cell dedifferentiation level in the pancreases of organ donors with differential risk for diabetes, such as different age layers, BMI, and HbA1c [15-18], as well as in T2DM patients, using NKX6.1 as dedifferentiation marker.

\section{Methods}

\section{Human subjects}

Human pancreata from 60 organ donors were obtained with between December 2016 and December 2019 with informed consents for research. We only included subjects who underwent a full autopsy within $4 \mathrm{~h}$ of death, pancreatitis, pancreatic surgery or cancer, and showed no signs of pancreatic autolysis. The information of organ donors was shown in Tables 1 and 2. Organ donors were firstly classified as ND with HbA1c $(<6.4 \%)$ and no history of diabetes $(n=40)$ and BMI, and sex matched T2D with HbA1c $(\geq 6.5 \%)$ or clinical history of diabetes (T2D, $n=20$ ). The ND controls were further sub-divided into different groups and the average data of each group was shown in Table 2 . ND subjects were divided into four age groups (30-49, 40-49, 50-59, 60-79 years) matched by BMI, HbA1c, sex and four BMI groups $(<23,23-25,25-30, \geq 30)$ matched by age, HbA1c, and sex. Besides the ND subjects were divided into $\mathrm{HbA} 1 \mathrm{c}<5.7 \%$ and HbA1c $5.7-6.4 \%$ which matched by age, BMI, sex. The Medical Ethical Committee of Tianjin First Central Hospital has approved all procedures (Review number:2016N079KY).

\section{Immunofluorescence analysis}

Human Pancreatic tissue was fixed with $10 \%$ formalin, followed by dehydration, paraffin embedding, and sectioning at $3 \mu \mathrm{m}$. Sections were then stained according to the protocol in one of our earlier studies [5]. After antigen retrieval of In brief, after deparaffinization, the paraffin sections were blocked with blocking buffer $(10 \%$ FBS, $0.1 \%$ Triton $\mathrm{X}-100$ ) for $30 \mathrm{~min}$ at $37^{\circ} \mathrm{Cfollowed}$ by sequential incubations with anti-NKX6.1 (1:500, NBP149672, Novus, USA) and anti-insulin (1:200, ab7842, Abcam, USA) at $4{ }^{\circ} \mathrm{C}$ overnight and secondary antibodies (Alexa Fluor 488 AffiniPure Goat Anti-Guinea Pig IgG H\&L, 1:200, 106-545-003, Jackson Immunoresearch Laboratories and Molecular Probes, USA; Rhodamine (TRITC) AffiniPure Goat Anti-Rabbit IgG H\&L, 1:100, 111-025-003, Jackson Immunoresearch Laboratories and Molecular Probes, USA) for $30 \mathrm{~min}$ at $37^{\circ} \mathrm{C}$, and then counterstained with DAPI. Pancreatic tissues were scanned by Pannoramic MIDI and Pannoramic Viewer (3DHistech).

Quantifications were performed in a blinded fashion using the CytoNuclear count function of the Image Pro Plus software (Media Cybernetics, Silver Spring, Maryland). Cells with a strong nucleic NKX6.1 immunreactivity in islet were described as nucleus NKX6.1 $1^{+}$cells, and cells with cytoplasmic or no NKX6.1 immunreactivity were described as nucleus NKX6.1- cells.

Table 1 Organ donor information from ND (Non-diabetic) and T2DM (type 2 diabetes mellitus) subjects

\begin{tabular}{llll}
\hline & BMI (kg/m2) & Age (years) & HbA1c (\%) \\
\hline ND $(n=40)$ & $26.27 \pm 0.75$ & $48.33 \pm 1.38$ & $5.34 \pm 0.07$ \\
T2DM $(n=20)$ & $25.72 \pm 0.62$ & $53.60 \pm 1.89^{*}$ & $7.58 \pm 0.28^{\dagger}$ \\
\hline
\end{tabular}

Data are shown as mean \pm SEM. ${ }^{*}$ compared with ND, $P<0.05 ;{ }^{\dagger}$ compared with ND, $P<0.0001$ 
Table 2 Organ donor information from ND (Non-diabetic) subjects

\begin{tabular}{|c|c|c|c|c|c|}
\hline & $N$ & BMI (kg/m2) & Age (years) & HbA1c (\%) & $\operatorname{sex}(M / F)$ \\
\hline \multicolumn{6}{|l|}{$\mathrm{HbA1c}(\%)$} \\
\hline $\mathrm{HbA1c}(\%,<5.7)$ & 32 & $25.69 \pm 0.77$ & $47.66 \pm 1.60$ & & $27 / 5$ \\
\hline $\mathrm{HbA} 1 \mathrm{c}(\%, 5.7-6.4)$ & 8 & $28.59 \pm 2.09$ & $51.00 \pm 2.54$ & & $5 / 3$ \\
\hline \multicolumn{6}{|l|}{ Age (years) } \\
\hline $30-39$ & 5 & $28.34 \pm 3.73$ & & $5.38 \pm 0.15$ & $4 / 1$ \\
\hline $40-49$ & 18 & $25.51 \pm 0.85$ & & $5.24 \pm 0.10$ & $16 / 2$ \\
\hline $50-59$ & 13 & $27.06 \pm 1.45$ & & $5.46 \pm 0.11$ & $9 / 4$ \\
\hline $60-79$ & 4 & $24.53 \pm 0.61$ & & $5.30 \pm 0.32$ & $3 / 1$ \\
\hline \multicolumn{6}{|l|}{ BMI (kg/m2) } \\
\hline$<23$ & 11 & & $48.00 \pm 2.09$ & $5.35 \pm 0.15$ & $9 / 2$ \\
\hline $23-25$ & 7 & & $47.86 \pm 3.49$ & $5.40 \pm 0.16$ & $7 / 0$ \\
\hline $25-30$ & 16 & & $48.94 \pm 2.57$ & $5.24 \pm 0.11$ & $13 / 3$ \\
\hline$\geq 30$ & 6 & & $47.83 \pm 3.51$ & $5.52 \pm 0.12$ & $3 / 3$ \\
\hline
\end{tabular}

M/F Males/Females. Data are shown as mean \pm SEM

\section{Statistical analysis}

Figure drawing and data processing were performed using GraphPad Prism v7.0 (GraphPad Software, La Jolla, CA, USA). Quantitative data were shown as means \pm SEM. Student's t test was used for analyzing the group differences. The sex-ratio were analyzed by chi-square test. $P<0.05$ were considered statistically significant.

\section{Results}

The characteristics of NKX6.1 defined $\beta$-cell dedifferentiation

By immunofluorescence staining with insulin and NKX 6.1 in human pancreatic tissue sections, we identified two types of dedifferentiated $\beta$ cells with NKX6.1 inactivation: 1) Cells that are insulin-positive but without nucleic NKX6.1 expression are at the early stage of dedifferentiated $\beta$ cells (NKX6.1 ${ }^{\text {Nuc- }}$ Ins $^{+}$, including $\beta$ cells with cytoplasmic NKX6.1 expression or no NKX6.1 expression, Fig. 1a-b); 2) Cells that are insulin-negative but with cytoplasmic expression of NKX6.1 are at the late stage of dedifferentiated $\beta$ cells (NKX6.1 ${ }^{\text {cyt }}$ Ins $^{-}$, Fig. 1a-b). The mean absolute number of NKX6.1 ${ }^{\mathrm{Nuc}^{-}} \mathrm{Ins}^{+}$cells per islet was 2.69 times that of NKX6.1 ${ }^{\text {cyt }} \mathrm{Ins}^{-}$cells. In addition, we also captured the $\beta$ cells with the expression of NKX6.1 in both nucleus and cytoplasm in the earlier stage of dedifferentiated $\beta$ cells, but that was rare. NKX6.1 dislocation or lost expression were signs of NKX6.1 inactivation. These results suggest different stages of NKX6.1 inactivation in the dynamic process of $\beta$-cell dedifferentiation.

The level of $\beta$ cell dedifferentiation with NKX6.1 inactivation was elevated and positively correlated with $\mathrm{HbA} 1 \mathrm{c}$ in type 2 diabetic subjects

We next evaluated the level of $\beta$-cell dedifferentiation with NKX6.1 inactivation in ND and T2DM subjects
(Fig. 2a). The absolute number of NKX6.1 ${ }^{\text {Nuc-}^{-}} \mathrm{Ins}^{+}$cells per islet in T2DM subjects were increased by $24.41 \%$ (Fig. 2b, $P<0.05$ ), and the percentage in $\beta$ cells increased by $61.56 \%$, compared with ND subjects (Fig. $2 \mathrm{~b}$, $P<0.001)$. The absolute number and percentage of NKX6.1 ${ }^{\text {cyt }}$ Ins $^{-}$cells per islet in T2D subjects increased by 2.41 and 2.31 fold, respectively (Fig. 2 c, $P<0.001, P<$ 0.001). We also found NKX6.1 ${ }^{\text {Nuc- }^{-} \mathrm{Ins}^{+}}$cells have a significant correlation with $\mathrm{HbA1c}$ in T2DM subjects (Fig. $2 \mathrm{~d}, P=0.03)$. These results suggest that the level of $\beta$ cell dedifferentiation in T2DM islet is elevated and aggravated by hyperglycemia.

\section{Modest hyperglycemia, advanced age, or obesity did not affect the level of $\beta$ cell dedifferentiation with NKX6.1 inactivation}

To evaluate the effect of modest hyperglycemia on $\beta$-cell dedifferentiation with NKX6.1 inactivation, the nondiabetic samples were further divided into the nonprediabetic group with normal glycaemia (HbA1c < $5.7 \%)$ and the prediabetic group with modest hyperglycemia (HbA1c: 5.7-6.4\%). The absolute number of

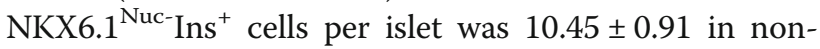
prediabetes and $9.00 \pm 1.67$ in prediabetes, respectively, and the percentage in $\beta$ cells was $16.31 \pm 1.15 \%$ and $16.68 \pm 2.40 \%$ (Table 3). The absolute number of NKX6.1 ${ }^{\text {cyt }}$ Ins $^{-}$cells per islet was $2.95 \pm 0.55$ and $2.04 \pm$ 0.91 , respectively, and the percentage per islet was $3.57 \pm 0.69 \%$ and $2.84 \pm 1.15 \%$, respectively (Table 3 ).

To analyze the effects of aging on $\beta$-Cell dedifferentiation with NKX6.1 inactivation, we further divided nondiabetic subjects into four groups with ages of 30-39, 40-49, 50-59, and 60-79, respectively. The absolute

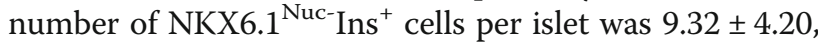
$11.63 \pm 0.92,8.95 \pm 1.29$, and $8.57 \pm 2.07$ in the four 


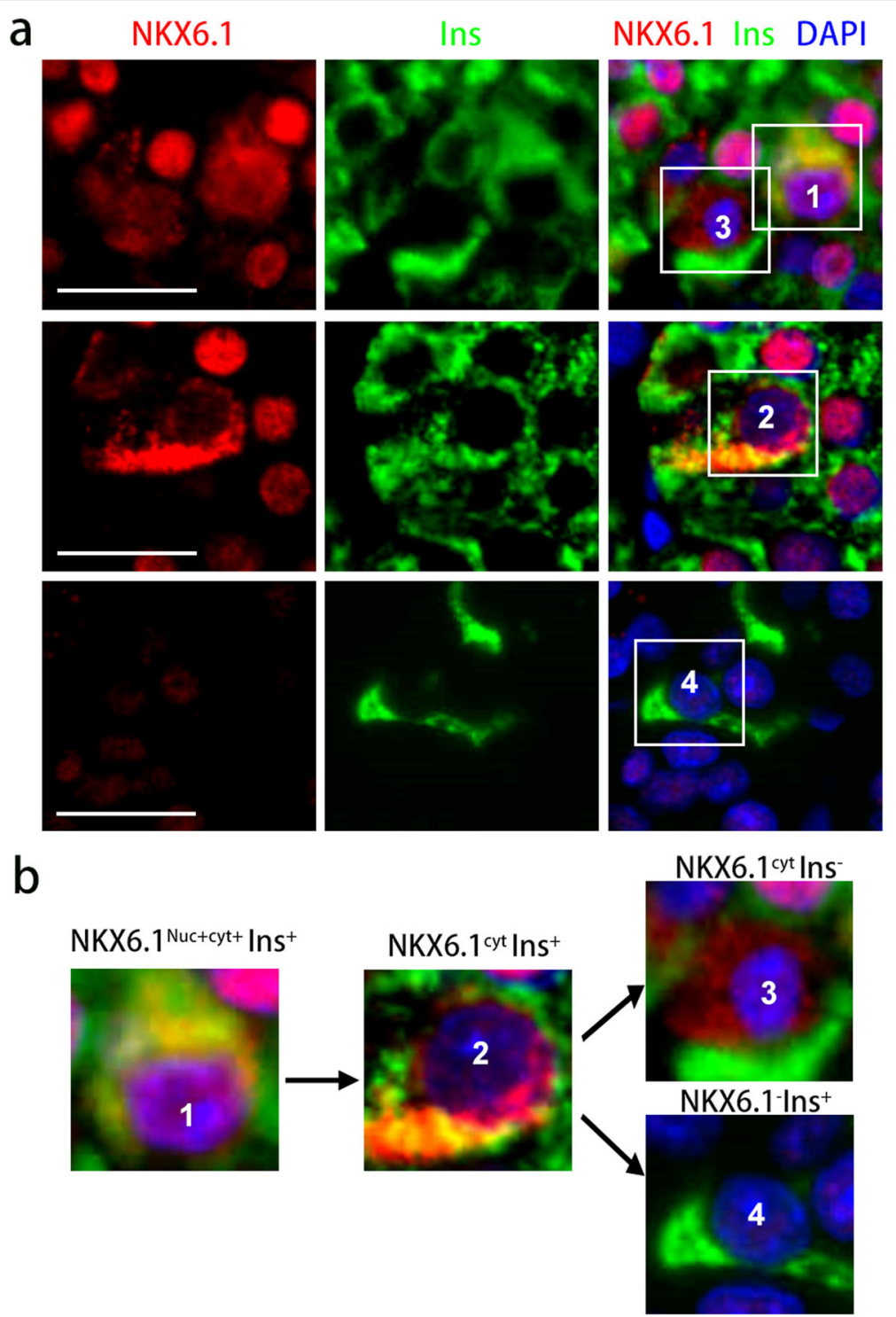

Fig. 1 Characteristics of dedifferentiated $\beta$ cells identified by NKX6.1. a Representative immunofluorescence images of pancreatic sections with NKX6.1 and Insulin (Ins). b Relationships among different dedifferentiated $\beta$ cell labeled by white boxes in (a). Scale bars: $20 \mu \mathrm{m}$, Red: NKX6.1, Green: Ins, Blue: DAPI

groups respectively, the percentages in $\beta$ cells was $13.19 \pm 3.56 \%, 18.20 \pm 1.16 \%, 15.72 \pm 2.02 \%$, and $14.40 \pm$ $4.03 \%$, respectively (Table 3 ). The absolute number of NKX6.1 ${ }^{\text {cyt }}$ Ins $^{-}$cells per islet was $3.05 \pm 1.16,2.71 \pm 0.82$, $2.16 \pm 0.58$, and $4.67 \pm 2.07$, the percentage per islet was $3.66 \pm 1.38 \%, \quad 3.24 \pm 1.00 \%, \quad 3.00 \pm 0.81 \%$, and $5.34 \pm$ $2.64 \%$, respectively (Table 3 ).

To analyze the effects of obesity on $\beta$-cell dedifferentiation with NKX6.1 inactivation, non-diabetic samples were divided into four groups according to the BMI standards for Asians special BMI: < 23 (normal), 23-25 (overweight), $25-30$ (obesity), $\geq 30$ (over-obesity). The

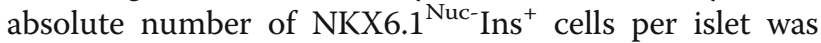
$12.64 \pm 1.64, \quad 9.69 \pm 1.71, \quad 9.41 \pm 1.24$, and $8.18 \pm 1.85$, respectively, the percentage in $\beta$ cells was $18.46 \pm 1.35 \%$, $15.90 \pm 2.21 \%, 15.92 \pm 1.96 \%$, and $14.40 \pm 2.73 \%$, respectively (Table 3). The absolute number of NKX6.1 ${ }^{\text {cyt }}$ Ins $^{-}$ cells per islet was $3.10 \pm 0.87,3.65 \pm 1.81,2.45 \pm 0.69$, and $1.98 \pm 0.53$, respectively, and the percentage per islet was $3.80 \pm 1.15 \%, 4.39 \pm 2.21 \%, 3.05 \pm 0.85 \%$, and $2.61 \pm$ $0.67 \%$, respectively (Table 3 ).

By statistical analysis, we found that there was no association between the number and percentage of NKX6.1 ${ }^{\text {Nuc- }} \mathrm{Ins}^{+}$and NKX6.1 ${ }^{\text {cyt }} \mathrm{Ins}^{-}$cells and modest hyperglycemia, advanced age, and obesity. Further correlation analysis between NKX6.1 ${ }^{\mathrm{Nuc}-} \mathrm{Ins}^{+}$or NKX6.1 $1^{\mathrm{cy}-}$ ${ }^{\mathrm{t}} \mathrm{Ins}^{-}$versus age/BMI/HbA1c found no significant correlation (Additional file 1: Supplementary Fig. 1-3). 


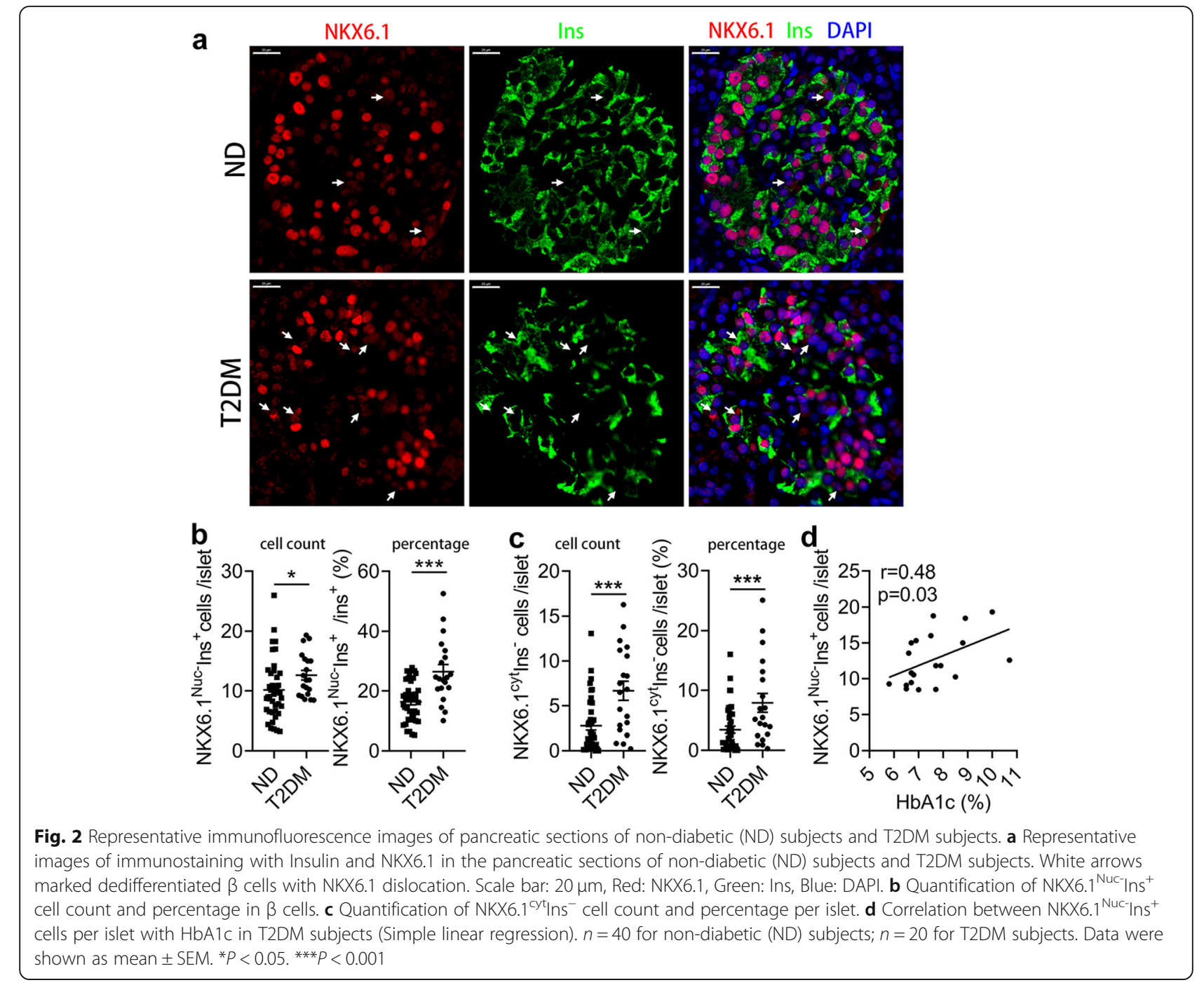

Table 3 Effect of high risk factors for type 2 diabetes mellitus on NXK6.1 Ins ${ }^{+}$cells and NKX6.1cyt Ins + cells per islet in pancreas

\begin{tabular}{|c|c|c|c|c|}
\hline & NXK6.1 ${ }^{\text {Nuc}_{-} \text {Ins }}{ }^{+}$cells /islet & NXK6.1 ${ }^{\text {Nuc- }}$ Ins ${ }^{+} /$ins $^{+}(\%)$ & 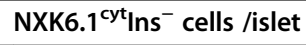 & NXK6. $1^{\text {cyt }}{ }^{\prime n s^{-}}$cells /islet (\%) \\
\hline \multicolumn{5}{|l|}{$\mathrm{HbA} 1 \mathrm{c}(\%)$} \\
\hline$<5.7 \%$ & $10.45 \pm 0.91$ & $16.31 \pm 1.15$ & $2.95 \pm 0.55$ & $3.57 \pm 0.69$ \\
\hline $5.7-6.4 \%$ & $9.00 \pm 1.67$ & $16.68 \pm 2.40$ & $2.04 \pm 0.91$ & $2.84 \pm 1.15$ \\
\hline \multicolumn{5}{|l|}{ Age (years) } \\
\hline $30-39$ & $9.32 \pm 4.20$ & $13.19 \pm 3.56$ & $3.05 \pm 1.16$ & $3.66 \pm 1.38$ \\
\hline $40-49$ & $11.63 \pm 0.92$ & $18.20 \pm 1.16$ & $2.71 \pm 0.82$ & $3.24 \pm 1.00$ \\
\hline $50-59$ & $8.95 \pm 1.29$ & $15.72 \pm 2.02$ & $2.16 \pm 0.58$ & $3.00 \pm 0.81$ \\
\hline $60-79$ & $8.57 \pm 2.07$ & $14.40 \pm 4.03$ & $4.67 \pm 2.07$ & $5.34 \pm 2.64$ \\
\hline \multicolumn{5}{|l|}{ BMI (kg/m2) } \\
\hline$<23$ & $12.64 \pm 1.64$ & $18.46 \pm 1.35$ & $3.10 \pm 0.87$ & $3.80 \pm 1.15$ \\
\hline $23-25$ & $9.69 \pm 1.71$ & $15.90 \pm 2.21$ & $3.65 \pm 1.81$ & $4.39 \pm 2.21$ \\
\hline $25-30$ & $9.41 \pm 1.24$ & $15.92 \pm 1.96$ & $2.45 \pm 0.69$ & $3.05 \pm 0.85$ \\
\hline$\geq 30$ & $8.18 \pm 1.85$ & $14.40 \pm 2.73$ & $1.98 \pm 0.53$ & $2.61 \pm 0.67$ \\
\hline
\end{tabular}

Data are shown as mean \pm SEM. No significant difference was observed between different groups 
These results suggested that higher risk factors for type 2 diabetes did not affect $\beta$-cell dedifferentiation in the non-diabetic subjects.

\section{Discussion}

The typical expression pattern of NKX6.1 in normal islets was in the nuclei of $\beta$ cells $[6,7,19]$. In this study, using immunofluorescence staining with NKX6.1 and insulin in human pancreatic sections, we firstly described the overall and subcellular expression pattern of NKX6.1 in human $\beta$ cells. Here we reported three more types of NKX6.1 expression patterns except its classic nucleic location: (1) both cytoplasmic location and nucleic location in single $\beta$ cells, (2) only cytoplasmic location, and (3) no expression in $\beta$ cells. Given NKX6.1 is an transcription factor, its cytoplasmic expression should be with no transcription activity, namely NKX6.1 inactivation. It was a pity that we could not provide the dynamic change of NKX6.1 expression pattern.

In this study, we investigated the expression pattern of NKX6.1 in islets from normal islets to T2DM islets, as well as in subjects with higher risks for developing diabetes. The number or percentage of $\beta$ cells with abnormal NKX6.1 expression significantly increased in subjects with T2DM. This finding is consistent with previous reports in other studies [7], and supports the concept that $\beta$ cell dedifferentiation is a mechanism for $\beta$ cell dysfunction in T2DM.

Our results revealed that the level of $\beta$-cell dedifferentiation with NKX6.1 inactivation positively correlated with HbA1c in T2DM subjects but not ND. This result is in accordance with previous report that $\beta$ cell dedifferentiation was elevated in T2DM islets $[7,14]$. However, whether $\beta$ cell dedifferentiation level has been elevated before T2DM is developed was previously unknown. In this study, we analyzed the level of NKX6.1 inactivation in $\beta$ cells of subjects with differential age, BMI, or HbA1c. We found no significant increase in NKX6.1marked $\beta$ cell dedifferentiation in subjects along with aging, obesity, or the modest increase of glycemia. These results suggested these risk factors didn't cause significant increase of $\beta$ cell dedifferentiation level in nondiabetic individuals. It's possible that $\beta$ cell dedifferentiation in T2DM subjects would deteriorate with the progression of this disease, but the $\beta$ cell dedifferentiation is only maintained at a basal level in ND subjects.

\section{Conclusions}

In summary, we report here that the level of $\beta$-cell dedifferentiation with NKX6.1 inactivation is significantly increased in Chinese people with type 2 diabetes. Importantly, the three risk factors for type 2 diabetes, including aging, obesity and modest hyperglycemia, did not affect the level of $\beta$-cell dedifferentiation in nondiabetic subjects.
Abbreviations

T2DM: Type 2 diabetes mellitus; ND: Non-diabetes; HbA1c: Glycated hemoglobin

\section{Supplementary Information}

The online version contains supplementary material available at https://doi. org/10.1186/s12902-021-00708-7.

\begin{abstract}
Additional file 1: Supplementary Fig. 1. Correlations between NKX6.1 inactivation level in $\beta$ cells and Age in non-diabetic subjects. a Correlation between NKX6.1 ${ }^{\text {Nuc-}}$ Ins $^{+}$cells count and percentage with Aging in Non-diabetic subjects $(n=40)$. b Correlation between NKX6.1 ${ }^{\text {cyt }} \mathrm{Ins}{ }^{-}$cell count and percentage with Aging in non-diabetic subjects $(n=40)$. Supplementary Fig. 2. Correlations between NKX6.1 inactivation level in $\beta$ cells and BMI in non-diabetic subjects. a Correlation between NKX6.1 Nuc- $^{-}$ns $^{+}$cells count and percentage with BMI in Non-diabetic subjects $(n=40)$. b Correlation between NKX6.1 ${ }^{\text {cyt }}$ Ins ${ }^{-}$cell count and percentage with BMI in non-diabetic subjects $(n=40)$. Supplementary Fig. 3. Correlations between NKX6.1 inactivation level in $\beta$ cells and HbA1C in nondiabetic subjects. a Correlation between NKX6.1 ${ }^{\text {Nuc}^{-}}$Ins $^{+}$cells count and percentage with $\mathrm{HbA} 1 \mathrm{c}$ in non-diabetic subjects $(n=40)$. b Correlation between NKX6.1 ${ }^{\text {cyt }}$ Ins ${ }^{-}$cell count and percentage with $\mathrm{HbA} 1 \mathrm{c}$ in nondiabetic subjects $(n=40)$
\end{abstract}

\section{Acknowledgements}

Our gratefulness was given to the organ donors for their great contributions for medical research.

\section{Authors' contributions}

S. W. and Z. S. conceived the study. T.L. drafted the manuscript, SW and RL reviwed and editied the manuscript.. T. L., P. S., J. Z., L. W., G. W., N. L., Y. L., X. D., and B. Z. participated in the design and implementation of this study. $T L$ analyzed the data and performed the figures and tables. All authors have read and approved the final manuscript.

\section{Funding}

This work was supported by grants from the National Natural Science Foundation of China (81870535), Key projects of Tianjin Natural Science Foundation (18JCZDJC33100), Chun Foundation of Tianjin First Central Hospital (2019CF05/01/37 and 2019CM01).

\section{Availability of data and materials}

The datasets generated and/or analysed during the current study are not publicly available due to that thourough analyses are still undergoing on the data produced by this project but are available from the corresponding author on reasonable request.

\section{Declarations}

Ethics approval and consent for participation Human pancreata from organ donors were obtained between December 2016 and December 2019.The donors or their relatives have specifically provided written informed consent for donated organs to be used in research. This study was approved by the Medical Ethical Committee of Tianjin First Central Hospital (Review number:2016N079KY).

Consent for publication

Not Applicable.

\section{Competing interests}

The authors declare that they have no competing interests.

\section{Author details}

'Organ Transplant Center, Tianjin First Central Hospital, Nankai University, Building A, Fukang Road 24\#, Nankai area, Tianjin City 300192, China. ${ }^{2} \mathrm{NHC}$ Key Laboratory for Critical Care Medicine, Tianjin First Central Hospital, Tianjin 300384, China. ${ }^{3}$ Tianjin Key Laboratory for Organ Transplantation, Tianjin First Central Hospital, Tianjin 300192, China. 
Received: 20 July 2020 Accepted: 23 February 2021

Published online: 12 March 2021

\section{References}

1. Federation ID. IDF Diabetes Atlas. 9th ed. Brussels; 2019. Available at: https:// www.diabetesatlas.org. Accessed 2020.

2. Li Y, Teng D, Shi X, Qin G, Qin Y, Quan H, Shi B, Sun H, Ba J, Chen B, et al. Prevalence of diabetes recorded in mainland China using 2018 diagnostic criteria from the American Diabetes Association: national cross sectional study. BMJ. 2020;369:m997.

3. Cohrs CM, Panzer JK, Drotar DM, Enos SJ, Kipke N, Chen C, Bozsak R, Schoniger E, Ehehalt F, Distler M, et al. Dysfunction of persisting beta cells is a key feature of early type 2 diabetes pathogenesis. Cell Rep. 2020;31(1): 107469

4. Weir GC, Gaglia J, Bonner-Weir S. Inadequate $\beta$-cell mass is essential for the pathogenesis of type 2 diabetes. Lancet Diabetes Endocrinol. 2020; 8(3):249-56.

5. Liu T, Liang R, Wang L, Zou J, Wang G, Liu N, Sun P, Liu Y, Ding X, Lu C, et al. Dynamic change of beta to alpha ratio in islets of Chinese people with Prediabetes and type 2 diabetes mellitus. Pancreas. 2020;49(5):692-8.

6. Talchai C, Xuan S, Lin HV, Sussel L, Accili D. Pancreatic beta cell dedifferentiation as a mechanism of diabetic beta cell failure. Cell. 2012; 150(6):1223-34.

7. Cinti F, Bouchi R, Kim-Muller JY, Ohmura Y, Sandoval PR, Masini M, Marselli $L$, Suleiman M, Ratner LE, Marchetti $P$, et al. Evidence of beta-cell dedifferentiation in human type 2 diabetes. J Clin Endocrinol Metab. 2016; 101(3):1044-54.

8. Butler AE, Dhawan S, Hoang J, Cory M, Zeng K, Fritsch H, Meier JJ, Rizza RA, Butler PC. Beta-cell deficit in obese type 2 diabetes, a minor role of beta-cell dedifferentiation and degranulation. J Clin Endocrinol Metab. 2016;101(2): 523-32.

9. Al-Khawaga S, Memon B, Butler AE, Taheri S, Abou-Samra AB, Abdelalim EM. Pathways governing development of stem cell-derived pancreatic beta cells: lessons from embryogenesis. Biol Rev Camb Philos Soc. 2018;93(1): 364-89.

10. Schaffer AE, Taylor BL, Benthuysen JR, Liu J, Thorel F, Yuan W, Jiao Y, Kaestner $\mathrm{KH}$, Herrera PL, Magnuson MA, et al. Nkx6.1 controls a gene regulatory network required for establishing and maintaining pancreatic Beta cell identity. PLoS Genet. 2013;9(1):e1003274.

11. Taylor BL, Liu FF, Sander M. Nkx6.1 is essential for maintaining the functional state of pancreatic beta cells. Cell Rep. 2013:4(6):1262-75.

12. Henseleit KD, Nelson SB, Kuhlbrodt K, Hennings JC, Ericson J, Sander M. NKX6 transcription factor activity is required for alpha- and beta-cell development in the pancreas. Development. 2005:132(13):3139-49.

13. Bensellam M, Jonas JC, Laybutt DR. Mechanisms of beta-cell dedifferentiation in diabetes: recent findings and future research directions. J Endocrinol. 2018;236(2):R109-43.

14. Guo S, Dai C, Guo M, Taylor B, Harmon JS, Sander M, Robertson RP, Powers AC, Stein R. Inactivation of specific beta cell transcription factors in type 2 diabetes. J Clin Invest. 2013;123(8):3305-16.

15. The American Diabetes Association (ADA). Introduction: Standards of Medical Care in Diabetes-2020. Diabetes Care. 2020:43(Suppl 1):S1-2.

16. Taylor R. Type 2 diabetes: etiology and reversibility. Diabetes Care. 2013; 36(4):1047-55.

17. Jia W, Weng J, Zhu D, Ji L, Lu J, Zhou Z, Zou D, Guo L, Ji Q, Chen L, et al. Standards of medical care for type 2 diabetes in China 2019. Diabetes Metab Res Rev. 2019;35(6):e3158.

18. Chatterjee S, Khunti K, Davies MJ. Type 2 diabetes. Lancet. 2017;389(10085): 2239-51.

19. Wang L, Liu T, Liang R, Wang G, Liu Y, Zou J, Liu N, Zhang B, Liu Y, Ding X, et al. Mesenchymal stem cells ameliorate beta cell dysfunction of human type 2 diabetic islets by reversing beta cell dedifferentiation. EBioMedicine. 2020;51:102615.

\section{Publisher's Note}

Springer Nature remains neutral with regard to jurisdictional claims in published maps and institutional affiliations.

\section{Ready to submit your research? Choose BMC and benefit from:}

- fast, convenient online submission

- thorough peer review by experienced researchers in your field

- rapid publication on acceptance

- support for research data, including large and complex data types

- gold Open Access which fosters wider collaboration and increased citations

- maximum visibility for your research: over $100 \mathrm{M}$ website views per year

At $\mathrm{BMC}$, research is always in progress.

Learn more biomedcentral.com/submissions 